\title{
On the essentials of international law in Xi Jinping Thought on the Rule of Law
}

Liu Huawen

Recibido: $25 / 06 / 2021$

\author{
hwliu@cass.org.cn \\ Pertenencia Institucional: Institute of International Law of \\ the Chinese Academy of Social Sciences - CASS (China)
}

Aceptado: 16/07/2021

\begin{abstract}
Xi Jinpings Thought on the Rule of Law was formally established in November, 2020 at the First Central Conference on Work Related to Overall Law-based Governance in the history of the Communist Party of China (CPC). It includes a wealth of ideas about international law, which are embodied in his propositions on and accounts of international law, and it has been developed under the current change of the world situation never seen for a century. Essentially, for his thought on international law, the core principles are the Five Principles of Peaceful Coexistence, and the central idea is to promote building a community with a shared future for mankind, and the main proposition is that the common values of mankind be the guideline for the global governance and international law. As reflected in his thought on the rule of law, the international governance of law is also closely related to the domestic rule of law. His propositions concerning the international governance of law shall be the important guidelines for China to study and practice international law, and will promote and then lead the progress and development of contemporary international law.
\end{abstract}

Keywords: Xi Jinping Thought on the Rule of Law; international law; community of a shared future for mankind; five principles of peaceful coexistence; international governance; global governance

* Cómo citar el artículo: Huawen, L. (2021). On the essentials of international law in Xi Jinping Thought on the Rule of Law. Relaciones Internacionales, 30(60), 133. https://doi.org/10.24215/23142766e133

Editor: Juan Alberto Rial, Instituto de Relaciones Internacionales Facultad de Ciencias Jurídicas y Sociales (Universidad Nacional de La Plata)
Entidad editora: Relaciones

Internacionales, es una publicación del Instituto de Relaciones Internacionales (Facultad de Ciencias Jurídicas y Sociales (Universidad Nacional de La Plata Argentina)

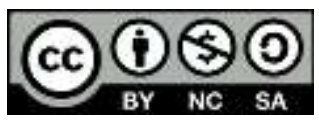

Reconocimiento-NoComercial Compartirlgual 4.0 Internacional (CC BY-NC-SA 4.0) 


\section{Sobre los fundamentos del derecho internacional en el Pen- samiento de Xi Jinping respecto del Estado de Derecho}

\section{Liu Huawen ${ }^{1}$}

Resumen: El Pensamiento de Xi Jinping respecto del Estado de Derecho se estableció formalmente en noviembre de 2020 durante la Primera Conferencia Central sobre el Trabajo Relacionado con la Gobernanza General basada en el Derecho en la historia del Partido Comunista Chino (PCC). Este pensamiento incluye una riqueza de ideas sobre el derecho internacional, las cuales se encuentran plasmadas en sus propuestas y relatos relativos al derecho internacional, y ha sido desarrollado durante los cambios actuales en la situación mundial, inéditos en el último siglo. En suma, para su pensamiento respecto del derecho internacional, los principios fundamentales son los cinco principios de coexistencia pacífica y la idea central es promover la construcción de una comunidad con un futuro compartido para toda la humanidad. Asimismo, la propuesta radica en que los valores comunes de la humanidad guíen la gobernanza global y el derecho internacional. Como puede apreciarse en sus ideas sobre el estado de derecho, la gobernanza internacional del derecho está íntimamente relacionada con el estado de derecho local. Sus propuestas en relación con la gobernanza internacional de derecho constituirán importantes lineamientos para que China estudie y ejerza el derecho internacional, y promoverán así como guiarán el progreso y el desarrollo del derecho internacional contemporáneo.

Palabras clave: el Pensamiento de Xi Jinping respecto del Estado de Derecho; derecho internacional; comunidad de un futuro compartido para la humanidad; cinco principios para la coexistencia pacífica; gobernanza internacional; gobernanza global

\footnotetext{
${ }^{1}$ Deputy Director and Researcher of the Institute of International Law of the Chinese Academy of Social Sciences (CASS), China.
} 
China is a country with a unique political system. The second paragraph of Article 1 of the Chinese Constitution clearly stipulates as follows: "The socialist system is the fundamental system of the People's Republic of China. The leadership of the Communist Party of China is the most essential feature of socialism with Chinese characteristics." Because of this, as the General Secretary of the Central Committee of the Communist Party of China (CPC), the Chairman of the Central Military Commission of CPC, and the President of China, $\mathrm{Xi}$ Jinping is the most representative figure in China's supreme leadership group. His public speeches and opinions actually represent the authoritative positions and propositions of the CPC and the Chinese government. In this sense, this article discusses the content of international law in Xi Jinping Thoughts on the Rule of Law, which has the effect of introducing China's position and propositions on international law.

The First Central Conference on Work Related to Overall Law-based Governance in the history of CPC on November 16 and 17, 2020, marked the establishment of Xi Jinping's thought on the Rule of Law and its status as the guiding thought for law-based governance in China. The meeting stressed that Xi Jinping's thought on the rule of law is rich in connotation, profound in exposition, rigorous in logic and complete in system, profoundly answering a series of major questions concerning why and how law-based governance should be advanced in the new era on the basis of the historical and contemporary coherence, international and domestic correlation, and the combination of theory and practice. ${ }^{2}$ Xi Jinping Thought on the Rule of Law includes both the rule of law at home and in matters involving foreign factors, and takes into account of both domestic and global governance. It encompasses a rich content of international law and answers to the international community the question of the times: "What is happening to the world and what should we do?"

Li Zhanshu, chairman of the Standing Committee of the National People's Congress (NPC), pointed out that Xi Jinping Thought on the Rule of Law is the latest achievement in adapting Marxist theories on the rule of law to the Chinese context, an important part of his Thought on Socialism with Chinese Characteristics for a New Era, and the fundamental guideline for law-based governance in China. ${ }^{3}$ The author believes that the establishment of Xi Jinping Thought on the Rule of Law is a major event for the building of the rule of law in China. It is a comprehensive overview and authoritative guideline to promote law-based governance in China at the political and cognitive levels. It is ta further development and improvement of Thought on Socialism with Chinese Characteristics, which marks that the advancing law-based governance in all fields has entered a better and faster development with clearer goals, more complete contents and more scientific paths. Xi Jinping's thought on international law is related to further reforming, advancing, opening up, and promoting

\footnotetext{
${ }^{2}$ Firmly follow the path of socialist rule of law with Chinese characteristics and provide strong rule of law guarantee for the comprehensive construction of a modern socialist country," People's Daily, Nov. 18, 2020, pp. 1, 4.

${ }^{3}$ The work of the NPC should seriously implement Xi Jinping's thought on the rule of law and perform its duties for the comprehensive construction of a modern socialist country," People's Daily, November 20, 2020, p. 1.
} 
economic development and social progress, as well as to economic globalization and the opportunities and challenges of maintaining peace and promoting development on a global scale. As China moves closer to the center of the world stage, its position, attitude, proposition and contributions to international law as the largest developing country are striking and increasingly have a broader and more profound impact.

Xi Jinping's propositions on international law cover a series of fundamental issues, such as the core concepts, principles and legal values of international law, the international governance of law and its relationship with the domestic rule of law. We need to develop a good grasp of Xi Jinping's thought on both the rule of law and international law, in the context of his overall Thought on Socialism with Chinese Characteristics for a New Era. As international law is closely related to international relations and diplomacy, Xi Jinping's thought on international law, which is often reflected in his important speeches and elaborations on international and diplomatic issues, is also closely related to his diplomatic thought.

\section{The changes unseen in a century are the basis and background of $X i$ Jinping Thought on the Rule of Law and his propositions on international law.}

\section{i. China's reform and opening up has been a great success}

Chinese legal studies are supposed to be based on Chinese reality and to connect theory with practice.

Looking back on the past forty years, the most certain reality in the global development process is "change". The biggest trend is to pursuit peace and development, and maybe the most prominent and successful one is the process of China's reform and opening up.

On August 22, 2016, the China National Human Development Report 2016 (the Report), released by the United Nations Development Programme (UNDP) and the Development Research Center of the State Council (DRCSC) of China, revealed some landmark statistics. Based on the Human Development Index (HDI), the Report declares that China has become one of the "ranks of countries with higher HDI" and one of the most progressive countries in the field of human development in decades. In 1980, at the beginning of the reform and opening up, China was in the bottom-ranked countries; after 1995, it entered the medium-ranked countries; after 2010, China's HDI began to surpass the world average, and in 2011, it reached the ranks of countries with higher HDI. Among the 47 bottom-ranked countries measured in 1990, China is the only one to one that has changed its fate through development and has risen into the ranks of the "high human development" countries. The Report notes that China's human development is reflected in all areas, including income, poverty reduction, health, and education. ${ }^{4}$ In other words, reflected behind the HDI is a profound change in China's national power. The rapid and mi-

\footnotetext{
${ }^{4}$ United Nations Development Programme, China, Development Research Center of the State Council, China Human Development Report 2016, China Translation Press, 2016, pp. 17-30.
} 
raculous development brought about by reform and opening up has made China the world's second largest economy and continues to put China at the forefront of sustainable development, scientific and technological innovation and application, and the most dynamic markets.

If the restoration of the People's Republic of China's (PRC's) lawful seat in the United Nations in 1971 was regarded as the beginning of China's political integration into the world family, the Beijing Olympic Games in 2008 was a symbol of China's wider and deeper cultural integration into the world, and the successful accession to the World Trade Organization (WTO) in 2001 was another milestone of China's integration into economic globalization. In the process of reform and opening up, China has found a development path that suits its national situations, and it is the reform and opening up that has made China a great success in development.

On October 29, 2020, the Fifth Plenary Session of the 19th CPC Central Committee adopted the "CPCCC's proposals for the formulation of the 14th Five-Year Plan (20212025) for National Economic and Social Development and the Long-Range Objectives Through the Year 2035" (hereinafter referred to as the "Proposals").

This important document points out that China's 13th Five-Year Plan period is the decisive stage in building a moderately prosperous society in all respects, and 2020 is its closing year, when "China has made significant breakthroughs in comprehensively deepening reform, advancing law-based governance, and enforcing strict Party governance. China's economic strength, scientific and technological strength, and comprehensive national power will leap to a new level". 5

China is on the verge of building a moderately prosperous society, and it is in the process of formulating the 14th Five-Year Plan and the 2035 Long-Range Objectives. According to the strategic arrangement of the 19th National Congress of the CPC to achieve the second century goal in two stages, China will basically realize socialist modernization in 2035 and build a great modern socialist country that is prosperous, strong, democratic, culturally advanced, harmonious, and beautiful by the middle of the 21st century.

China is closer than ever to realizing the Chinese Dream of national rejuvenation. $\mathrm{Xi}$ Jinping's thought on the rule of law is based on China's reality and reflects not only the achievements in the process of reformation and opening up, but also the basic experience, essential needs and development direction in the construction of the rule of law in the process of China's realization from getting rich to getting strong.

The rule of law is inseparable from reformation and opening up. Xi Jinping even looks upon the rule of law from the perspective of the rise and decline of nations and states, often quoting the words of Han Feizi in ancient China: "No country is forever strong or eternally weak. When those who enforce the law have strength, the country will be strong;

\footnotetext{
${ }^{5}$ Proposal of the Central Committee of the Communist Party of China on Formulating the Fourteenth FiveYear Plan for National Economic and Social Development and the Visionary Goals for 2035, People's Daily, November 4, 2020, p. 1.
} 
when they are weak, it too will be weak. No country is always weak. "6

\section{ii. The most revolutionary change in global power configuration.}

Xi Jinping pointed out, "China is at present in its best period of development in modern times, while the world is undergoing the most profound and unprecedented changes in a century. These two realities are intertwined and mutually influential." ${ }^{17}$ The international community is generally peaceful and the development process as a whole is in a progressive trend. In the new context of economic globalization, breakthroughs and applications of science and technology, especially in the fields of transportation, communications, medicine, biology, the internet, and artificial intelligence have brought great changes to human society and unprecedented potential for world development. Not only are developed countries developing, but developing countries are developing more significantly too, and their share in the world economy and their contribution to the world economic development are becoming larger and larger. The proposition that the world is in the midst of great changes that have not been seen in a century is a scientific overview of the international situation by Xi Jinping. The "change" here is not only a quantitative change, but also a qualitative one.

On October 12, 2015, when the Political Bureau of the CPC Central Committee held a group study session on the theme of global governance and its mechanism, Xi Jinping pointed out that, "It is commonly believed in the international community that change in the global governance system has now reached a historic juncture. The International balance of power has seen profound change, with emerging markets and a large number of developing countries growing space and gaining increasing international influence in what is the most revolutionary shift in the balance of international power since the dawn of modern times." 8

The development of international democratization, through the decolonization movement from the 1950s to the 1970s and then through the economic development of countries in the past decades, have changed significantly. In terms of the international power configuration, the asymmetry of the absolute dominance of Western developed countries no longer exists, and it is more realistic and feasible for developing countries to participate in multilateral international mechanisms on an equal footing politically, economically and legally as sovereign states and members of the United Nations. Even small

\footnotetext{
${ }^{6} \mathrm{Xi}$ Jinping, "Speech at the second full assembly of the Fourth Plenary Session of the $18^{\text {th }}$ CPC Central Committee ", Xi Jinping, The Law-Based Governance of China, Central Compilation \& Translation Press, English version, 2017. pp.12,13.

${ }^{7} \mathrm{Xi}$ Jinping, "Using the Thought on Diplomacy for New-Era Socialism with Chinese Characteristics as a Guide to Create a New Landscape in Major Country Diplomacy with Chinese Characteristics" , Xi Jinping, On Building a Human Community with a shared future, Central Compilation \& Translation Press, English version, 2019, p.551. pp.258,259.

${ }^{8} \mathrm{Xi}$ Jinping, "Championing Discussion and Collaboration for Shared Growth as a Principle of Global Governance ", Xi Jinping, On Building a Human Community with a shared future, p. 270.
} 
and medium-sized countries can use international rules to assert their rights, make contributions to global governance in areas such as climate change and sustainable development, and win support and obtain victories under the framework of international law. This is unprecedented or uncommon in human history.

The world is in the midst of great changes that have not been seen in a century. For China, it means a century-long change from being poor and weak, and being bullied and plundered by the Western powers, to standing up, getting rich and strong after the founding of New China, and getting closer than ever to realizing the Chinese Dream of national rejuvenation. For the world, it is a remarkable transformation of the international landscape, from one dominated by a few Western powers to one dominated by many both developed countries and major developing countries in a multi-polar pattern. The world is more closely connected with each other, and there are more and more cross-border and global threats, such as climate change, natural disasters, epidemic diseases, energy and resource crises, food crises, armed conflicts such as weapons of destruction and mass destruction, and the collapse of internet systems and databases. The common interests and the common destiny of mankind are being challenged more, and there is a greater need to pay attention to the change of needs and trends.

In 2020, the sudden COVID-19 pandemic disrupted the rhythm of life and development of people around the world. For example, people's health and life safety were threatened, travel was greatly restricted, the health crisis outside China failed to be effectively resolved on a large scale and for a long time, uncertainty increased, emergency management became the norm, the world economy faced greater risk of stagnation and regression, and the international order and system were under greater impact. That is, the pandemic has highlighted the objective reality that the destinies of human societies are closely linked and that global crises should be tackled together. The developed countries in the West have not performed significantly better than the developing countries when response to the epidemic. The unity of all countries in the fight against the pandemic is a fundamental guarantee for the ultimate victory over the pandemic. The trend of multipolarization has become more obvious, and China's constructive role in the international arena has become more prominent, as it has actively engaged in international assistance and cooperation while maintaining its own fight against the pandemic. The sudden onslaught caused by the COVID-19 pandemic has accelerated the once-in-a-century transformation in an increasingly fluid and changing world.

On September 21, 2020, Xi Jinping pointed out that "China was the first to sign the Charter of the United Nations. It is a founding member of the UN and the only developing country that takes a permanent seat on the Security Council. China will continue to be a true follower of multilateralism. It will stay actively engaged in reforming and developing the global governance system. It will firmly uphold the UN-centered international system, firmly uphold the international order underpinned by international law, and firmly defend the UN's central role in international affairs." ${ }^{9} \mathrm{Xi}$ Jinping Thought on the Rule of Law and

\footnotetext{
${ }^{9}$ Xi Jinping, "Speech at the 75th Anniversary Summit of the United Nations", People's Daily, September 21, Continúa en la próxima página
} 
his propositions on international law have realized the coherence between history and contemporary times, the correlation between domestic and international context.

\section{The Five Principles of Peaceful Coexistence and building a global com- munity of shared future for mankind are the core principles and con- cepts of Xi Jinping's thoughts regarding international law}

\section{i. Provisions of the Party Constitution and China's Constitution}

In October 2017, the 19th National Congress of the Communist Party of China (CPC) formally established Xi Jinping's Thought on Socialism with Chinese Characteristics for a New Era. In the report of the 19th National Congress, Xi Jinping proposed the concept of "major-country diplomacy with distinctive Chinese features" and put forward the new idea of "two constructs" for foreign relations, namely, building a new type of international relations and building a global community of shared future. In the report, Xi Jinping emphasized that China adheres to the concept of global governance based on the principles of extensive consultation, joint contribution and shared benefits, advocates the democratization of international relations, insists on the equality of all countries regardless of their size and strength, supports the active role of the United Nations, and supports the developing countries' rights of representation and speech in international affairs. China will continue to play the role of a responsible major country, actively participate in the reform and construction of the global governance system, and continuously contribute Chinese wisdom and strength.

On October 24, 2017, the 19th National Congress of the Communist Party of China adopted the "Constitution of the CPC (Amendment)". The amendment incorporates "uphold justice", "building a global community of shared future" and "follow the principle of achieving shared growth through discussion and collaboration, and pursue the Belt and Road Initiative" in the general outline of the Party Constitution. In the first Article of the general rules, the Party Constitution clearly stipulates that the CPC "is the leadership core for the cause of socialism with Chinese characteristics", and Article 1, paragraph 2 of the Chinese Constitution clearly states that "Leadership of the Communist Party of China is the most essential attribute of socialism with Chinese characteristics". This shows that, in China, the will of the Party and the will of the State are closely related and organically unified.

Subsequently, on March 11, 2018, the First Session of the Thirteenth National People's Congress considered and adopted the "Amendment to the Constitution of the People's Republic of China", in which in the twelfth paragraph of the preamble of the Constitution, after the words "China adheres to an independent foreign policy as well as to the five principles of mutual respect for sovereignty and territorial integrity, mutual nonaggression, non-interference in each other's internal affairs, equality and mutual benefit,

2020, p. 2.

240 Relaciones Internacionales Vol 30 - № 60/2021 
and peaceful coexistence", the phrase "to the path of peaceful development, and to the reciprocal, win-win and open strategy" is added; and "promoting the building of a community with a shared future for mankind" was added after the phrase "developing diplomatic relations and economic and cultural exchanges with other countries". It was Xi Jinping that first proposed the building of a community with a shared future for mankind, which was formally incorporated into the Constitution. ${ }^{10}$ In China, the preamble of the Constitution is an important part of its content and has the same supreme legal effect as the main text. ${ }^{11}$ It is the legalization of the Party's theories, policies and guidelines, meaning that on the basis of adhering to the Five Principles of Peaceful Coexistence, promoting the building of a community with a shared future for mankind has become China's constitutional position and constitutional principle. The status of the Constitution as the fundamental law of the country determines that the Five Principles of Peaceful Coexistence and the promotion of the building of a community with a shared future, which appear simultaneously in the preamble of the Chinese Constitution, are the fundamental guidelines for China's handling of foreign relations.

Regarding how to adhere to the independent foreign policy of peace, the road of peaceful development, the justice, the five principles of peaceful coexistence, the promotion of building a community of shared future and the construction of the "Belt and Road" in the new historical period, Xi Jinping has made a series of important speeches and has made many original judgments, generalizations and elaboration. The gradual formation of Xi Jinping's thoughts on diplomacy and the rule of law and their embodiment in the Party constitution and the Constitution is of historic significance. It is the symbolic and authoritative embodiment of the formation of Xi Jinping's Thought on Socialism with Chinese Characteristics in the new era, and guides the formulation and implementation of Party and state policies and laws, as well as the practice of China's domestic and external construction and development.

\section{ii. Dialectical unity of core principles and concepts}

The Five Principles of Peaceful Coexistence, which were put forward by the first generation of Chinese leaders in the 1950s, have not become obsolete today, and they continue to shine with new luster through the ages. Xi Jinping's Thought on Socialism with Chinese Characteristics in the New Era is the result of the collective wisdom of the Chinese Communists in building and developing China, and the Five Principles of Peaceful Coexistence remain an important element in his Diplomatic Thought and his Thought on the Rule

\footnotetext{
${ }^{10}$ The concept and idea of a community of shared future for mankind was first formally introduced in an international setting by Chinese President Xi Jinping in a speech at the Institute of International Relations in Moscow, Russia, on March 23, 2013. Xi Jinping, "Following the Trends of our Time and Promoting World Peace and Development", Xi Jinping, On Building a Human Community with a shared future, p. 7.

${ }^{11}$ See Zhang Cong, "The Preamble of the Constitution also has the highest legal effect - Interview with Li Lin, Member of the Chinese Academy of Social Sciences (CASS) and former Director of the Institute of Law, CASS, in People's Daily, March 9, 2018, p. 14; Xu Chongde, History of the Constitution of the People's Republic of China, Fujian People's Publishing House, 2005, p. 481.
} 
of Law.

The Five Principles of Peaceful Coexistence and the building of a community with a shared future are the core principles and concepts of Xi Jinping's thought on international law. In international law, it is particularly worth paying attention to the significance and value of the Five Principles of Peaceful Coexistence as the basic principles of international law in interstate interaction and cooperation, and the status and influence of building of a community with a shared future as a concept and principle in the formulation, development and practice of international law. The two have a relationship of inheritance and development, mutual reinforcing and dialectical unity. The Five Principles of Peaceful Coexistence are the foundation, especially reflecting the bottom-line thinking of safeguarding national sovereignty and territorial integrity, non-interference in internal affairs and peaceful coexistence, while the building of a community with a shared future focuses on the whole and the long-term affairs, reflecting the new trend and vision of human society and highlighting the guideline of the international rule of law in the new era. The two are not opposites or substitutes for one other, but together they constitute China's views, positions and propositions on the basic issues of the world's current situation and development. $^{12}$

The Five Principles of Peaceful Coexistence are norms of international law pioneered by China, a contribution of China to international law, and a highlight in the history of the development of international law. Adherence to the Five Principles of Peaceful Coexistence has been written in the vast majority of bilateral treaties on the establishment of diplomatic relations between China and other countries, and is reflected in such international documents as the Declaration on Principles of International Law adopted by the UN General Assembly in 1970, and the Charter of Economic Rights and Duties of States adopted by the UN General Assembly in 1974. It means that countries with different social systems, levels of development and economic power can, in accordance with the Five Principles of Peaceful Coexistence, be equal in legal status, achieve a balance of rights and obligations in mutual relations, respect each other and live together peacefully. It is a progress in modern international law and a progress in the history of the development of international relations. This historic progress did not happen overnight or once and for all. For example, The Government of Mauritius has not yet recovered the Chagos Archipelago, which was "leased" by the British, and the historic decolonization movement since the establishment of the United Nations has hardly come to an end. Cases of unilateralism, bullying of the weak by the strong, bullying of the small by the large, violation of the basic norms of international law and breach of the basic norms of international relations are not uncommon today. The Five Principles of Peaceful Coexistence are not obsolete and remain the basis of international law. On October 18, 2017, Xi Jinping stated in his report to the 19th Party Congress that "China will continue to hold high the banner of peace, development, cooperation, and mutual benefit and uphold its fundamental foreign policy goal of

\footnotetext{
${ }^{12} \mathrm{Xu}$ Hong, "The Community of Shared Future of Mankind and International Law," Chinese Review of International Law, Issue 5, 2018, pp.8-10
} 
preserving world peace and promoting common development. China remains firm in its commitment to strengthening friendship and cooperation with other countries on the basis of the Five Principles of Peaceful Coexistence, and to forging a new form of international relations featuring mutual respect, fairness, justice, and win-win cooperation. ${ }^{13}$ In his speech at the fifth summit of the Conference on Interaction and Confidence-building Measures in Asia (CICA) on June 15, 2019, Xi Jinping said, "China will stay committed to peaceful development and reject a beggar-thy-neighbor approach. China will continue to deepen its friendship and cooperation with other countries on the basis of the Five Principles of Peaceful Co-existence, pursue peaceful settlement to disputes with relevant countries over territorial sovereignty and maritime rights and interests, and support negotiated solutions to regional hotspot issues." 14

Legal concepts and thoughts should be dealt with in a balanced way. The Five Principles of Peaceful Coexistence mentions "cooperation for mutual benefit" and "peaceful coexistence", which actually reflects the consideration of the international community as a whole. When Xi Jinping proposed the idea of building a community of shared future, he emphasized the overall interests and common interests of all mankind in a more timely and clear manner based on the new realities and trends of the international community, and emphasized the new goals and visions of global governance. Building a community of shared future is the goal and direction of international governance and an inevitable choice to solve the current crises and challenges facing the international community, which requires all countries in the world to raise awareness, form consensus and take action.

At the same time, it should be seen that building a global community of shared future needs to be based on the present practice, and adherence to the basic norms of international relations and pragmatic advancement within the framework of existing international law. A useful and effective basic guideline for actively, constructively and sustainably promoting the building of a community with a shared future is to continue to attach importance to and adhere to the Five Principles of Peaceful Coexistence, and on this basis, increase mutual trust and develop cooperation. It is not advisable to be too conservative or too radical.

In the author's view, among the propositions of Xi Jinping's thought involving international law, the Five Principles of Peaceful Coexistence and the building of a community of a shared future for mankind are an organic whole, and there is a relationship between the path and the goal, which also contains the implication of combining small and big goals, and immediate and long-term goals.

\footnotetext{
${ }^{13} \mathrm{Xi}$ Jinping, Building a moderately prosperous society across the board and seizing the great victory of socialism with Chinese characteristics in the new era - Report at the 19th National Congress of the Communist Party of China, People's Publishing House, 2017, p. 58.

${ }^{14} \mathrm{Xi}$ Jinping, "Working Together for New Progress of Security and Development in Asia- Speech at the Fifth Summit of the Conference on Interaction and Confidence-Building Measures in Asia (CICA)", People's Daily, June 16, 2019, p.2.
} 


\section{The Common Values of Humanity of Xi Jinping Thought on the Rule of Law are the values that lead the development of global governance and international law}

\section{i. Common Values of Humanity as the guiding values of global governance}

The rule of law is not only the rule of rules, but also the rule of values. Aristotle believed that the ultimate purpose of the law is to promote justice and good morality, and that its authority is part of the moral ideal. ${ }^{15}$ The good law and good governance pursued in the domestic rule of law is reflected in the core values of domestic society, which in China are called the Socialist Core Values. The international rule of law also requires guiding values. Professor He Zhipeng believes that the understanding of international law should not remain only at the level of the rules themselves, but must establish relevant value standards. Establishing the value standards of international law is not only conducive to our understanding and judgment of international law, but also has a very important role in the reform and development of international law.

Faced with the question of where international law should go, Zhao Hong, then a Chinese member of the World Trade Organization Appellate Body, pointed out at the first International Law Forum of the Munich Security Conference on February 13, 2020: "We have to admit that the development of international law is at a crossroads. Compared to the current state of development of the rule of law at the national level, the international governance of law is still in the early stages or even in its infancy stage of development. (...) Transforming the international governance of law from a concept to a reality in international relations is supposed to be more challenging. The realization of this process requires a high sense of morality and self-discipline on the part of the various sovereign participants." ${ }^{16}$ This sense of morality and self-discipline spirit undoubtedly requires the guidance of legal values.

On September 28, 2015, President Xi Jinping attended the general debate of the 70th session of the United Nations General Assembly at the UN headquarters and delivered an important speech, stressing that "Peace, development, fairness, justice, democracy, and freedom are Common Values of Humanity and also the lofty goals of the United Nations. Yet these goals are far from being achieved; therefore, we must continue our endeavors." ${ }^{17}$ The United Nations is the most universal and important multilateral coordination center in the world, and Xi's innovative overview of the common values of all mankind as the mission shared by all countries and the UN can be said to be a worldwide reminder to the international community to remember the original purpose for which the

\footnotetext{
${ }^{15}$ See [Ancient Greek] Aristotle, Politics, translated by Wu Shoupeng, Commercial Press, 1965, p. 138.

${ }^{16}$ Zhao Hong, "International Law at the Crossroads: Ideals and Realities of the International Rule of Law," International Trade, Issue 2, 2020, p. 7.

${ }^{17}$ Xi Jinping, "A new Partnership of Mutual Benefit and Community of Shared Future," in Xi Jinping, Governance of China, Vol. II, Foreign Languages Press, English version, 2017, p. 522.
} 
UN was established and not to forget the goals of international governance. Since then, on different occasions, Xi Jinping has repeatedly emphasized Common Values of Humanity and highlighted value guidance.

The Universal Declaration of Human Rights (UDHR), adopted by the United Nations General Assembly on December 10, 1948, was the first universal and comprehensive international human rights document in history, and was the basis for a series of core human rights treaties developed and promoted by the United Nations since then. The International Covenant on Civil and Political Rights (ICCPR), the International Covenant on Economic, Social and Cultural Rights (ICESCR), and the UDHR are known as the "International Bill of Human Rights". On December 10, 2018, Xi Jinping reiterated in a congratulatory letter to the symposium jointly organized by the China Society for Human Rights Studies and the China Foundation for Human Rights Development to commemorate the 70th anniversary of the UDHR: "Together with the peoples of other countries, and based on the Common Values of Humanity - peace, development, equity, justice, democracy and freedom-China is committed to safeguarding human dignity and rights, and promoting a fairer, more equitable and inclusive global governance of human rights, so as to build a global community of shared future and strive for a better world." 18 In this congratulatory letter, Xi linked Common Values of Humanity to global human rights governance and the building of human community with a shared future for mankind. This is the reflection of the leading role of common human values in the field of international human rights law.

In 2020, the COVID-19 pandemic raged around the world, and countries experienced a major challenge that has occurred once-in-a-century since World War II. In this year, China is emphasizing more prominently than ever the preservation of multilateralism. On September 22, 2020, Xi Jinping participated by video in the general debate of the 75th session of the United Nations General Assembly in Beijing and stressed once again in his speech: "Let us join hands to uphold the values of peace, development, equity, justice, democracy and freedom shared by all of us and build a new type of international relations and a community with a shared future for mankind. Together, we can make the world a better place for everyone. ${ }^{19}$ On October 23, 2020, Xi Jinping again emphasized in his speech at the 70th anniversary of the Chinese People's Volunteers entering the Democratic People's Republic of Korea to fight in the War to Resist US Aggression and Aid Korea, "As a responsible great power, China adheres to the common values of peace, development, fairness, justice, democracy and freedom for all mankind, stay committed to the vision of consultation, cooperation and benefit for all in global governance, and unswervingly follows the path of peaceful development, open development, cooperative development and common development." ${ }^{20}$ As can be seen, Xi Jinping has repeatedly linked common human

\footnotetext{
${ }^{18} \mathrm{Xi}$ Jinping, "Protect and Promote Human Rights in the Chinese Context," in Xi Jinping, Governance of China,Vol. III, Foreign Languages Press, English version, 2020, pp. 337.

${ }^{19} \mathrm{Xi}$ Jinping, "Taking the Road of Human Rights Development in Accordance with National Conditions," in Xi Jinping, Governance of China, Vol. III, p. 288.

${ }^{20} \mathrm{Xi}$ Jinping: "Speech at the Conference Commemorating the 70th Anniversary of the Chinese People's Volunteer Army's Fight Against the U.S. and Aid North Korea", People's Daily, October 24, 2020, p. 2.
} 
values to global governance in a comprehensive manner.

\section{ii. Common human values as the legal values of international law}

Xi Jinping did not directly address the legal values of international law, but he has repeatedly and explicitly elaborated on the value guidance of global governance at the United Nations and other important occasions. This author believes that international law is not only a legal form of global governance, but also a more normative, stable, and predictable form that is not only indispensable but also an advanced form of governance, as the value system guiding global governance can be further applied to the realm of international law. It is believed as well that the common human values proposed by Xi Jinping are of great significance in international law and can be argued as legal values that lead the development and operation of international law.

"Peace" is the primary value of the modern international law system. Zhou Gengsheng, a famous Chinese international jurist, said: "International law should be in the service of peace for mankind. It should be the basic task of modern international law science to clarify and enrich the democratic principles that are conducive to peace. (...) Needless to say, in this direction, to promote the development of modern international law is to consolidate the legal basis of international peace."

Peace and development are the fundamental purposes of the UN Charter and the basic values from which international law emerged and developed. Peace provides conditions for development, and economic and social development can lay the foundation for peace and consolidate and promote it. ${ }^{21}$ On September 3, 2015, Xi Jinping pointed out in his speech at the Conference Commemorating the 70th anniversary of the victory of the Chinese People's War of Resistance against Japanese Aggression and the World AntiFascist War: "Today, peace and development have become the prevailing trend, but the world is far from tranquil. War is the sword of Damocles that still hangs over mankind. (...) All countries should jointly uphold the international order and system underpinned by the purposes and principles of the UN Charter, build a new model of international relations based on mutually beneficial cooperation, and advance the noble cause of global peace and development." 22 The year 2015 marked the 70th anniversary of the United Nations, and on September 26 of the same year, Xi Jinping delivered a speech at the United Nations Sustainable Development Summit 2015, noting that "At the global level, peace and development remain the dominant themes of the times. To properly address the range of global challenges we face, including the recent refugee crisis in Europe, there is no fundamental solution other than the pursuit of peace and development. Confronted by such a multiplicity of challenges and difficulties, we must hold fast to development as our master key, for only through development can we resolve the root cause of conflicts, safeguard the basic

\footnotetext{
${ }^{21}$ Jon Barnett,Peace and Development,"Towards a New Synthesis",Journal of Peace Research, Vol. 45, No. 1,2008, pp.75-89.

${ }^{22}$ Xi Jinping, "Remember the Past and Our Martyrs, Cherish Peace, and Build a New Future," in Xi Jinping, Governance of China, Vol. II, p.485.
} 
rights of the people, and meet the ardent hopes of people for a better future." ${ }^{23}$

Fairness and justice are legal values common to both domestic and international law. When talking about the rule of law, Xi Jinping places great emphasis on the value of fairness and justice in law. In his speech at the First Meeting of the Commission for Law-based Governance under the CPC Central Committee on August 24, 2018, Xi Jinping pointed out that "We must uphold social equity and justice, which is the goal of the rule of law, and make sure that the people can see that equity and justice are served in every law, every law enforcement action, and every judicial case."24

In international law, justice and fairness play the same legal function as domestic law to distinguish right from wrong. On June 28, 2014, Xi Jinping pointed out at the Meeting Marking the 60th Anniversary of the Initiation of the Five Principles of Peaceful Coexistence that all countries should jointly promote the rule of law in international relations. We should urge all parties to abide by international law and well-recognized basic principles governing international relations and use widely applicable rules to tell right from wrong and pursue peace and development. ${ }^{25}$ On November 17, 2020, at the 12th meeting of BRICS leaders, Xi Jinping pointed out: "Facing the choice between multilateralism and unilateralism, and between justice and hegemony, we BRICS countries must stand up for equity and justice in the world. We must hold high the banner of multilateralism, and defend the purposes and principles of the Charter of the United Nations. We must endeavor to safeguard the UN-centered international system and the international order underpinned by international law." 26

Democracy and freedom are fundamental political values, the product of the development of human civilization, which are both pursued by domestic constitutions and laws, as well as values respected and advocated by international law. Sovereign equality is the basic principle of international law and the cornerstone of democratization of international relations. In international law, different countries have equal sovereignty and all peoples enjoy the right to determine their own path of development and to obtain free development in all political, economic and cultural aspects, in accordance with the Charter of the United Nations and other basic documents of international law. In the preamble of the UN Charter, it is mentioned that "We the peoples of the United Nations determined to (...) promote social progress and better standards of life in larger freedom". ${ }^{27}$ The International

\footnotetext{
${ }^{23}$ Xi Jinping, "Toward a Mutually Beneficial Partnership for Sustainable Development", Xi Jinping, On Building a Human Community with a shared future, pp. 258,259.

${ }^{24}$ Xi Jinping, "Advance the Rule of Law Under the Chinese Socialism," in Xi Jinping, Governance of China, Vol. III, p. 333.

${ }^{25} \mathrm{Xi}$ Jinping, "Championing the Five Principles of Peaceful Coexistence, Building a Better World Through Win-Win Cooperation", Xi Jinping, On Building a Human Community with a shared future, p. 141.

${ }^{26}$ Xi Jinping, "Watch and Help Each Other to Overcome the Pandemic and Work Together to Advance Cooperation", People's Daily, November 18, 2020, p.2.

27 Charter of the United Nations, cited from the United Nations website, https://www.un.org/zh/sections/un-charter/preamble/index.html, accessed on November 20, 2020.
} 
Covenant on Civil and Political Rights (ICCPR) and the International Covenant on Economic, Social and Cultural Rights (ICESCR), known as the "Two Covenants on Human Rights" of the United Nations, explicitly state in their identically worded common Article 1, paragraph 1: "All peoples have the right of self-determination. By virtue of that right they freely determine their political status and freely pursue their economic, social and cultural development." ${ }^{28}$ On March 20, 2005, then UN Secretary-General Kofi Annan presented a famous report on a range of major issues, including UN reform and development, that laid the groundwork for a summit of world leaders, taking its name from the key phrase "In larger freedom" in the Preamble to the UN Charter, entitled "In Larger Freedom: Towards Development, Security and Human Rights for All". ${ }^{29}$ The need to respect and observe democratic principles in the creation and operation of international law, and to guarantee the rights and freedoms of States and their peoples, individually and collectively, is the new understanding of modern international law.

In his speech at the 18th Meeting of the Council of Heads of State of the Shanghai Cooperation Organization (SCO) on June 10, 2018, Xi Jinping noted that "[w]hile hegemony and power politics still persist in this world, the growing call for a more just and equitable international order must be heeded. Democracy in international relations has become an unstoppable trend." ${ }^{30}$ On January 18, 2017, Xi Jinping stressed in his speech at the United Nations headquarters in Geneva that "[s]overeign equality is the most important norm governing state-to-state relations over the past centuries, and the cardinal principle observed by the United Nations and its agencies and institutions. The essence of sovereign equality is that the sovereignty and dignity of all countries, whether big or small, strong or weak, rich or poor, must be respected, their internal affairs brook no interference and they have the right to independently choose their social system and development path. (...) In a new era, we should uphold sovereign equality and work for equality in enjoying rights and opportunity and making and observing rules." ${ }^{11}$ At the same time, China itself is a developing country, and Xi Jinping stressed that "We must uphold our commitment to speaking on behalf of developing countries and to strengthen solidarity and cooperation with them." 32 On September 28, 2015, at the general debate session of the 70th UN General Assembly, $\mathrm{Xi}$ also specifically mentioned that "Consultation is an important form of democracy, and it

\footnotetext{
${ }^{28}$ International Covenant on Civil and Political Rights and International Covenant on Economic, Social and Cultural Rights, Office of the United Nations High Commissioner for Human Rights, cited respectively from the United Nations website, https://www.un.org/zh/documents/treaty/files/A-RES-2200-XXI-2-new. shtml,https://www.un.org/zh/documents/treaty/files/A-RES-2200-XXI-new.shtml, last visited on November 20, 2020.

${ }^{29}$ United Nations document: A/59/2005/Add.3.

${ }^{30} \mathrm{Xi}$ Jinping: "Carry forward the Shanghai Spirit; Build a Community of Shared Future", in Xi Jinping, Governance of China, Vol. III, p. 511.

${ }^{31}$ Xi Jinping, "Toward a Community of Shared Future for Mankind," in Xi Jinping, Governance of China, Vol. II, pp. 590,591.

${ }^{32} \mathrm{Xi}$ Jinping, "Improving Our Ability to Participate in Global Governance", Xi Jinping, On Building a Human Community with a shared future, p. 397.
} 
should also become an important means of conducting contemporary international governance. We should resolve disputes and differences through dialogue and consultation." ${ }^{33}$

As a Chinese leader, Xi Jinping's understanding of rights and freedoms in international occasions is people-centered and closely linked to the UN's development agenda. In his speech at the UN Sustainable Development Summit on September 26, 2015, he said that "Development bears on the hopes and the very survival of the peoples of all countries. It embodies the expression of their dignity and their rights"; the international community should take the Post-2015 Development Agenda adopted by this summit as a new starting point, "work out a course of equitable, open, all-round and innovation-driven development, and strive to realize the common development of all countries"; "Development is ultimately for the benefit of the people. While striving to eliminate poverty and improve standards of living, it is important for us to uphold equality and social justice and ensure that everyone has access to the opportunities and benefits of development." 34

The above-mentioned Xi Jinping's outline, elaboration and emphasis on Common Values of Humanity are value guidelines for the international community to exchange, cooperate, join hands to face challenges and move into the future, and are legal values that guide the progress and development of modern international law, representing an important contribution of China to the world of international jurisprudence.

\section{Xi Jinping Thought on the Rule of Law reflects the organic link between domestic Rule of Law and international Rule of Law}

\section{i. China's strengthening of its foreign relations through international law and attaches importance to the international governance of law}

In today's world, a country's development cannot be isolated from the whole world, and the domestic and international interests are becoming more and more closely linked.

National interactions and competition in today's world are more often conducted under the form of law. For example, legal battles involving core national interests such as maritime delimitation and maritime interests are attracting attention; international law is intertwined with domestic law, and the trade war between China and the United States, marked by the raising of tariffs, has a wide impact; the achievements in climate change are also consolidated and put into practice in the form of international treaties; the development of international human rights law and international human rights mechanisms are also having far-reaching effects.

\footnotetext{
${ }^{33} \mathrm{Xi}$ Jinping, "Working Together to Forge a New Partnership of Mutually Beneficial Cooperation and Create a Human Community with a Shared Future", Xi Jinping, On Building a Human Community with a shared future, p. 265.

${ }^{34}$ Xi Jinpin, "Toward a Mutually Beneficial Partnership for Sustainable Development", Xi Jinping, On Building a Human Community with a shared future, pp.258,259.
} 
China has become the world's second largest economy and will continue to insist on deepening reform and expanding opening up. Under the unprecedented changes unseen in a century, China advocates multilateralism and promotes international rule of law and global governance in an active, responsible and constructive manner. At this time, China attaches even greater importance and attention to international law. The "CPC Central Committee's Decision on Some Major Issues Concerning How to Uphold and Improve the System of Socialism with Chinese Characteristics and Advance the Modernization of China's System and Capacity for Governance" adopted in the Fourth Plenary Session of the 19th CPC Central Committee, clearly proposed that "foreign-related rule of law work should be strengthened, a legal system for foreign-related work should be established, research and application of international law should be strengthened, and the level of rule of law in foreign-related work should be improved." 35

The Chinese international jurisprudence community has compared this statement with the words of Deng Xiaoping on December 13, 1978: "We should vigorously strengthen the study of international law", ${ }^{36}$ and considered it to be of great significance.

International law is, first and foremost, at the service of the country's foreign communication. International law is the "traffic rules" for the country to "go abroad" and the "manual" and "handbook" for foreign exchanges and cooperation. International law provides the legal basis and legal expression for national positions and claims. Further, international law is an operational institutional framework and institutional guarantee of national interests, claims and pursuits. At the same time, in connection with the international governance of law, what kind of international order and system of international rules that should be established is itself part of the national interest.

According to a survey of the Global Diplomacy Index (GDI) released by the Australian think tank Lowy Institute for International Policy, China's total number of embassies and consulates abroad would surpass that of the United States in 2019 to become the world's number one, as the number of new diplomatic relations has increased in recent years. By January 2020, China had established diplomatic relations with 180 countries, established partnerships with 112 countries and international organizations, participated in more than 100 intergovernmental international organizations, and signed more than 500 multilateral treaties, advancing China's diplomatic agenda in a comprehensive, multilevel, multifaceted way. ${ }^{37}$

\footnotetext{
${ }^{35}$ Decision of the Central Committee of the Communist Party of China on Several Major Issues on Adhering to and Improving the Socialist System with Chinese Characteristics and Promoting the Modernization of the State Governance System and Governance Capacity, People's Publishing House, 2019, p. 38.

${ }^{36}$ Deng Xiaoping, "Emancipating the Mind, Seeking Truth from Facts, Uniting to Look Forward", Deng Xiaoping, Selected Works of Deng Xiaoping, Vol. II, People's Publishing House, 2008, p. 147.

${ }^{37}$ Foreign Ministry Spokesperson Geng Shuang's regular press conference on January 8, 2020 , Webpage of the Chinese Ministry of Foreign Affairs:

https://www.fmprc.gov.cn/web/wjdt_674879/fyrbt_674889/t1730274.shtml, last visited on November $22,2020$.
} 
It is worth noting that the Fifth Plenary Session of the 19th CPC Central Committee adopted the "CPCCC's proposals for the Formulation of the 14th Five-Year Plan (20212025) for National Economic and Social Development and the Long-Range Objectives Through the Year 2035" specifically proposed in paragraph 59: "China will strive to create a favorable external environment and hold high the banner of peace, development, cooperation, and mutual benefit, and uphold the independent foreign policy of peace, and promote the building of a new type of international relations and a community with a shared future for humanity." ${ }^{13}$ As can be seen, in addition to specialized governmental diplomatic departments and their diplomats, and foreign-related organs and the public officials in other government departments, the foreign relations of social organizations, institutions, etc. are also valued.

The strength of China's foreign engagement is gradually increasing. One of the successful experiences of China's reform and opening up over the past 40 years is that we have attached importance to international law and increasingly use it to integrate into the international community, actively engage in international cooperation in various fields such as the international economy, politics, education, science and technology, culture and sports, and effectively safeguard our legitimate rights and interests, while increasingly playing a role in the formulation and development of international law. The "Resolution of the Central Committee of the Communist Party of China on Major Issues Concerning Comprehensively Advancing the Rule of Law"adopted at the Fourth Plenary Session of the 18th CPC Central Committee specifically mentions the strengthening of foreign-related legal work, and in the resolutions adopted at the Fourth and Fifth Plenary Sessions of the 19th CPC Central Committee, the wording is changed to "the rule of law involving foreign factors", so it can be said that the awareness and importance of foreign-related laws and related work mechanisms have gone up to a higher level, including, of course, the importance of international law and its application.

When it comes to the rule of law, there are three concepts: the rule of law at home and in matters involving foreign factors and international governance of law. From China's position, the rule of law includes the rule of law at home and in matters involving foreign factors; from the perspective of the international community, China actively participates in the international governance of law based on international law. In the author's view, international governance of law is an important form of international governance, and emphasizing the totality of the world. International governance is also called global governance. In order to prevent the concept of global governance from being too idealized, and based on the fact that international society mainly consists of states as the basic subjects, international governance often cannot ignore the existence of national borders, the name of international governance seems to be more accurate.

Usually, the concepts of international governance and global governance are used

\footnotetext{
38"Proposal of the Central Committee of the Communist Party of China on Formulating the Fourteenth FiveYear Plan for National Economic and Social Development and the Visionary Goals for 2035", People's Daily, November 4, 2020, p. 4.
} 
complementarily or interchangeably with each other. ${ }^{39}$

In particular, since the 18th Party Congress, China has even more actively participated in the work of the United Nations, proposed and promoted the "Belt and Road" construction, initiated the establishment of new multilateral financial institutions such as the Asian Infrastructure Investment Bank(AIIB), contributed to the reform of the International Monetary Fund(IMF) and other specialized agencies of the United Nations, and actively participated in the formulation of governance rules in emerging areas such as oceans, polar regions, networks, outer space, nuclear security, anti-corruption and climate change. Xi Jinping said, "We should take economic development as the central task, and concentrate our efforts on managing our town affairs well to keep improving our capacity to speak and act on the international stage. We should actively participate in global governance and willingly shoulder international responsibilities. We must do all we can within the limitations of our capacities. "40

The unprecedented importance China attaches to foreign-related rule of law and global governance will greatly promote the popularization, study and application of international law in China, which will be conducive to the development of China's domestic rule of law and foreign-related rule of law, as well as the development of international governance of law worldwide.

\section{ii. International law and domestic law as closely related and the rule of law at home and the need to integrate the rule of law involving foreign factors.}

On August 14, 2020, the exchange meeting on the creation of child-friendly towns in China and the launching ceremony of child-friendly towns in Dayun, hosted by the China Children's Center and organized by the People's Government of Dayun, Jiashan County, Jiaxing City, Zhejiang Province, was officially held. Experts organizing the project pointed out that a child-friendly town refers to a city, town, community or any local government system that is committed to realizing the rights of children as stipulated in the Convention on the Rights of the Child (CRC). ${ }^{41}$ This is a new example of incorporating an international law perspective or factor into domestic grassroots governance.

International law, especially international human rights law and international law related to the United Nations development agenda, is closely related to domestic rule of law and social governance. Accurate understanding, assessment and application of interna-

\footnotetext{
${ }^{39}$ James W. Davis,"A Critical View of Global Governance", Swiss Political Science Review, Vol. 18, No. 2,2012, pp. 272-286.

${ }^{40} \mathrm{Xi}$ Jinpin, "Improving Our Ability to Participate in Global Governance", Xi Jinping, On Building a Human Community with a shared future, p.397.

${ }^{41}$ Nansu, "The First Child-Friendly Town Creation in China Launched," Zhejiang Daily, August 18, 2020, p. 11. See Lina Zong et al. "A Chinese Solution for Innovative Child-Friendly City Construction - Ecological Construction of Child-Friendly Education Complex in China Children's Center," Beijing Planning and Construction, No. 3, 2020.
} 
tional standards and international experience can help modernize grassroots governance and its innovation in China.

China's legislation is first formulated in accordance with its own Constitution and based on its own national conditions, but will also examine and consider international experience and social development trends. While emphasizing China's specific situation, $\mathrm{Xi}$ Jinping pointed out that "the rule of law is one of the important accomplishments of human civilization. Its quintessence and gist have universal significance for the national and social governance of all countries. Therefore, we must learn from the achievements of other countries." 42 Both foreign law and international law can reflect international experience and the achievements of legal civilization, while international law is more likely to reflect universally accepted legal principles or rules, and has special significance for absorption and reference. China attaches importance to the domestic implementation of international treaties ratified or acceded to by the country, and to the implementation of general international law and various rules of international law with corresponding legal effect on China, while international treaties to which China is not a party or other rules of international law that do not have legal effect may still have reference value on legal culture.

In the process of building China under the rule of law, international law will inevitably influence domestic law, while domestic law will communicate with international law and contribute to the development of international law as well, including the formulation and implementation of the rules of international law and the reform, improvement and development of the international law system. The level of organic integration of domestic law and international law is also an important aspect of building the rule of law in China.

In November 2020, Xi Jinping proposed in his speech at the CPC Central Committee Conference on Work Related to Overall Law-based Governance that we should take a coordinated approach to promoting the rule of law at home and the rule of law involving foreign factors; accelerate the strategic layout of foreign-related rule of law work, coordinate the promotion of domestic and international governance, and better safeguard national sovereignty, security and development interests; strengthen rule of law thinking, apply the rule of law, effectively respond to challenges and prevent risks, and make comprehensive use of legislation to strengthen the rule of law, use the rule of law, effectively respond to challenges, prevent risks, make comprehensive use of legislation, law enforcement, justice and other means to carry out the struggle, and resolutely safeguard national sovereignty, dignity and core interests; to promote global governance improvements, and promote the building of a community of shared future for mankind. ${ }^{43}$

An example of the coordinated approach to promoting the rule of law at home and

\footnotetext{
${ }^{42}$ Xi Jinping, "Promote Socialist Rule of Law," Xi Jinping, The Governance of China, Vol. II, Foreign Languages Press, English version, 2017, p. 126.

43 "Unswervingly Follow the Path of the Socialist Rule of Law with Chinese Characteristics, and Provide a Strong Legal Guarantee for the Comprehensive Construction of a Modern Socialist Country", People's Daily, November 18, 2020, pp. 1 and 4.
} 
in matters involving foreign factors is the extraterritorial application of a country's laws. The Fourth Plenary Session of the 19th CPC Central Committee paid attention to the extraterritorial application of China's law. ${ }^{44}$ This has put forward higher requirements for China's legislation. Today, as economic globalization continues to advance and the domestic and international interests are closely linked, the formulation of each law should be examined from the perspective of international law, including the possibility of international law providing the basis and support for the extraterritorial application of relevant Chinese laws, as well as the necessity, feasibility and impact of the extraterritorial application of Chinese laws now and in the future. As a developing country, the construction of China's system of extraterritorial application of laws is not a task that can be accomplished by any one or a few laws, nor is it a matter that can be accomplished overnight or once and for all, but it rather requires long-term and persistent efforts and promotion.

In the process of taking a coordinated approach to promoting the rule of law at home and in matters involving foreign parties and promoting domestic and international governance, the international law awareness and international law thinking of leading cadres, especially legislators and policy makers, should be constantly strengthened. In other words, the role of international law talents is very crucial.

On October 23, 2014, the Resolution of the Central Committee of the Communist Party of China on Major Issues Concerning Comprehensively Advancing the Rule of Law, adopted at the Fourth Plenary Session of the 18th CPC Central Committee, mentioned the cultivation of the law talents who are well-versed in international legal rules and adept at handling foreign-related legal affairs. ${ }^{45} \mathrm{Xi}$ Jinping attached great importance to this point, as he pointed out at the 35th group study session of the Political Bureau of the 19th CPC Central Committee on September 27, 2016: "We need to improve our ability to participate in global governance, putting particular weight on the ability to make rules, set agendas, and to communicate and coordinate. To be effective in global governance, we need a large number of professionals who have a good knowledge of policies and principles of the Party and government, understand our national conditions, possess a global outlook and a good command of foreign languages, and are conversant with international rules and skilled in international negotiations. We should strengthen the training of high-caliber personnel involved in global governance, and ensure we have adequately trained professionals in our talent tool to offer robust personnel support for our participation in global governance."46

The level of international law research is the basis and the core. International law teaching is a great plan for the long term, and the application of international law is an

\footnotetext{
${ }^{44}$ Decision of the Central Committee of the Communist Party of China on Several Major Issues on Adhering to and Improving the Socialist System with Chinese Characteristics and Promoting the Modernization of the State Governance System and Governance Capacity, People's Publishing House, 2019, pp. 14, 38.

${ }^{45}$ Guidance Readings on the Decision of the Central Committee of the Communist Party of China on Several Major Issues of Comprehensively Promoting the Rule of Law, People's Publishing House, 2018, p. 33.

${ }^{46}$ Xi Jinpin, "Improving our Ability to Participate in Global Governance", Xi Jinping, On Building a Human Community with a shared future, pp.398,399.
} 
important need and an urgent task in China's development process at present and in the future. ${ }^{47}$ Further strengthening the study and application of international law is an important aspect of strengthening the national governance system and building the capacity of governance.

\section{Xi Jinping's Propositions on International Law as Important Guidance for the Progress and Development of Modern International Law}

\section{i. China's upholding of the international order based on international law}

The "Proposals" adopted by the Fifth Plenary Session of the 19th CPC Central Committee once again emphasize "strengthening the application of international law", specifically "adhering to multilateralism and the principle of extensive consultation, joint contribution and shared benefits, actively participating in the reform and construction of the global governance system, strengthening the construction of the foreign-related rule of law system, strengthening the application of international law, and maintaining the international system with the United Nations at its core and the international order based on international law." ${ }^{48}$ As can be seen, the place of international law in the programmatic documents of the Chinese Communist Party is now particularly prominent. The fact that international law is used as the basis for China's claims about the international order is an unprecedented emphasis, and the esteem for international law is also an important development and unprecedented in China's view of the rule of law and its thinking. This is inseparable from the progress and development of the international law system over the past seventy years since the establishment of the United Nations, and is even more relevant to the current international situation, including the international challenges and development trends.

After World War II, the development of international law has become different from traditional international law, with a broader and more universal scope of application. Third World countries have become independent and stronger, changing the international landscape. The level of democratization and the rule of law of international community has surpassed any other stage in history. International law itself has advanced and developed in different areas and to different degrees in the sense of procedural and substantive law. Of course, International law is far from perfect, and the phenomenon of "legal uncertainty" in different fields is still prominent; ${ }^{49}$ the safeguard mechanism for the implementation

\footnotetext{
${ }^{47}$ See Huang Jin, "How to Strengthen the Cultivation of Foreign-Related Rule of Law Talents," Legal Daily, November 20, 2019, p. 9; Huang Huikang, Great Power Diplomacy with Chinese Characteristics and International Law, Law Press, 2019, p. 494.

${ }^{48}$ Proposal of the Central Committee of the Communist Party of China on Formulating the Fourteenth FiveYear Plan for National Economic and Social Development and the Visionary Goals for 2035, People's Daily, November 4, 2020, p. 4.

${ }^{49}$ See Jia Bingbing, "An Analysis of the Problem of "Legal Uncertainty" in International Law", Chinese International Law Society, Chinese Yearbook of International Law, vol. 2013, Law Press, 2014, pp. 73-92.
} 
of international law is sometimes still weak. However, the importance of international law for the maintenance of world peace and development has become more and more prominent. Many areas, such as adaptation to and participation in economic globalization, response to non-traditional security threats such as large-scale armed conflicts or terrorism, collaboration in the application of science and technology, are impossible without rules and require the existence of international law everywhere. ${ }^{50}$

The international system with the United Nations at its core does not have the power of the so-called "world government" or the coercive power of the "world police" or international armed forces, but only the legal values, purposes and principles based on the UN Charter and general international law, the rule of law, especially the governance of international law.

It is not surprising that international law has been violated and undermined by some countries from time to time throughout history; however, unlike in the past, no country today would completely ignore the existence of international law. In the face of violations and breaches of international law, rather than raising query about the legal nature and status of international law, the international community is prompted to further promote respect for and compliance with international law. Xi Jinping pointed out: "With the increase in global challenges, a strengthening of global governance and the advance of change in the global governance system has come to be the general trend. This is not only about responding to global challenges but also about determining the rules and directions for the international order and system. (...) The conflicts and injustices of today's world arise not because the purposes and the principles of the UN Charter have become outdated, but because those same purposes and principles are not effectively acted on." ${ }^{51}$

The Fifth Plenary Session of the 19th Party Central Committee specifically mentioned in its "Proposals" that "we will actively participate in international cooperation to prevent and control major infectious diseases. and promote the building of a global community of health for all." 52 This is an aspect of the international rule of law, as well as a specific example of the opportunities and challenges facing international law, that will receive much attention and make greater progress over the next several years and even longer.

The year 2020 was too extraordinary a year. The world pandemic of COVID-19 is a major human challenge once in a blue moon. The entire planet is actually one under the threat of the epidemic. ${ }^{53}$ This confirms the idea of the human community with a shared

\footnotetext{
${ }^{50}$ Malcolm N. Shaw, International Law, 8th edition, Cambridge University Press, 2017, pp.301-302.

${ }^{51}$ Xi Jinping, "Championing Discussion and Collaboration for Shared Growth as a Principle of Global Governance", Xi Jinping, On Building a Human Community with a Shared Future, p.271.

52"Proposal of the Central Committee of the Communist Party of China on Formulating the Fourteenth FiveYear Plan for National Economic and Social Development and the Visionary Goals for 2035", People's Daily, p. 4.

${ }^{53}$ See Katharine Wright \& Julian Sheather, "The Role of Solidarity in Research in Global Health Emergencies

",The American Journal of Bioethics, vol. 20, no. 5, 2020, p. 4.
} 
future that Chinese President Xi Jinping has long proposed. China has long seen the reality and development of the solidarity of all countries and their people, and has demonstrated a spirit of responsibility, commitment and altruism in the response to the epidemic. Science and law are important features of China's response to the epidemic. Scientific understanding and response are the foundation, and the law is the rules to carry out the work. China was the first to report the outbreak to the World Health Organization and to share with the world the latest findings and related results, such as gene sequencing. While responding to its own epidemic, China has been lending a helping hand to other countries, and has been stepping up its foreign assistance and actively advocating and providing international public goods in the health sector after its own epidemic response has achieved a stage of success. In the course of the epidemic response, China has been consistent in its words and actions, and is an example of upholding multilateralism, complying with international law and promoting the building of a community with a shared future for mankind.

\section{ii. Opposing the hegemony and unilateralism of individual powers}

In contrast to China, the U.S. government has been demonstrating unilateralism, isolationism, and pragmatism in the field of international law in recent years, readily exercising long-arm jurisdiction over other countries or adopting unilateral sanctions, and also constantly withdrawing from international treaties and international organizations or threatening to withdraw from them. In the course of the response to the 2020 epidemic, the U.S. government's remarks related to the stigmatization of the epidemic and those involving racial discrimination were dismaying. While the U.S. failed to effectively prevent and control the pandemic at home, it also seriously defaulted on its UN dues and even attacked and withdrew from the World Health Organization, not only failing to show the responsible attitude expected of the largest developed country, but even backtracking when the world needed solidarity the most. It has become a negative energy that has a serious negative impact on international governance, especially the international governance of law. For example, the dispute settlement mechanism of the World Trade Organization has been paralyzed due to the United States' hamstrings.

Where is the international community heading? The unprecedented changes of the century are even more disturbing and thought-provoking. On February 27, 2017, UN Secretary-General António Guterres attended the opening of the 34th session of the Human Rights Council and delivered his first speech to the Council as Secretary General. He noted that the world is becoming a more dangerous, unpredictable and chaotic place, where old conflicts are not over and new ones are beginning to emerge. ${ }^{54}$ Certainty and predictability are essential features of the rule of law, and the effectiveness of international governance depends on the establishment and maintenance of an international order based on international law and on due respect for and compliance with international law by all countries,

\footnotetext{
${ }^{54}$ António Guterres, Remarks to the UN Human Rights Council, 27 February 2017, www.un.org/sg/en/content/sg/speeches/2017-02-27/ secretary-generals-human-rights-council-remarks, last visited on November 22, 2020.
} 
especially the major powers and countries with interests in different fields.

In a speech at the United Nations headquarters in Geneva on January 18, 2017, Xi Jinping said, "The relevance of law lies in its enforcement. It is thus incumbent on all countries to uphold the authority of the international rule of law, exercise their rights in accordance with law and fulfill their obligations in good faith. The relevance of law also lies in fairness and justice. All UN member states and international judicial institutions should ensure equal and uniform application of international law and reject double standards or selective application of international law, thus ensuring genuine equality and justice in the world." And then he also stressed that "[w]e should advance democracy in international relations and reject dominance by just one or several countries. All countries are entitled to shape the future of the world, making international rules, managing global affairs and sharing the fruits of development." ${ }^{55}$ On September 21, 2020, in his speech at the 75th anniversary summit of the United Nations, Xi again emphasized very clearly the need for the UN to "uphold the rule of law" saying, "[r] elations among countries and coordination of their interests must only be based on rules and institutions; they must not be lorded over by those who wave a strong fist at others. Big countries should lead by example in advocating and upholding the international governance of law and in honoring their commitments. There must be no practice of exceptionalism or double standards. Nor should international law be distorted and used as a pretext to undermine other countries' legitimate rights and interests or world peace and stability." 56

In recent years, against the backdrop of a growing international governance deficit, China has been emphasizing multilateralism and supporting the United Nations in its active role as the most important universal international organization, while stressing that it is a staunch defender and builder of the international governance of law. ${ }^{57}$ Italian scholars Maria Francesca Staiano and Fabio Marcelli compare the characteristics of the prevention and control of the 2020 COVID-19 pandemic in different countries, particularly Italy and China, and identify the historical divergence and practical limitations of crisis response mechanisms under the EU framework, noting that the 2020 COVID-19 pandemic highlights established conflicts at the regional and global levels and raises the urgent need to innovate existing global and regional governance, while also providing an opportunity to explore the new concept of human community with a shared future. ${ }^{58}$

The COVID-19 pandemic is a major challenge that highlights the shortcomings of global governance. The propositions and series of discourses involving international law in

\footnotetext{
${ }^{55} \mathrm{X}$ Jinping, "Towards a Community of Shared Future for Mankind," Xi Jinping, Governance of China, Vol. II, pp.591,592.

${ }^{56} \mathrm{Xi}$ Jinping, "Speech at the Summit Commemorating the 75th Anniversary of the Founding of the United Nations", People's Daily, September 22, 2020, p.2.

${ }^{57}$ See Wang Yi, "China is a Firm Defender and Builder of the International Rule of Law," Guangming Daily, October 24, 2014, p. 2.

58 [Italian] Maria Francesca Staiano, Fabio Marcelli, "Challenges, Reflections and Prospects of the COVID-19 Global Epidemic", translated by Li Jiang, Chinese Review of International Law, Issue 4, 2020, pp. 3-23.
} 
Xi Jinping Thought on the Rule of Law are comprehensive and balanced. While adhering to the Five Principles of Peaceful Coexistence, Xi Jinping advocates actively promoting the building of a community with a shared future, which is conducive to the Chinese safeguarding of their sovereignty, security and development interests, as well as the establishment of a new type of international relations and promoting the building of a community with a shared future, which is in line with modern international law with sovereign states as the basic subject. At the same time, peace, development, fairness, justice, democracy and freedom as the common values of humanity can thus strongly promote the progress and development of modern international law. Especially when solving global problems faced by all mankind in the world, the proposition and concept of promoting the construction of a community of shared future has extremely important leading and innovative significance. ${ }^{59}$

Xi Jinping had a firm confidence in the world's general situation, saying, "[t] he COVID-19 pandemic has added to the instability and uncertainty facing the world economy. However, looking back at history, humanity has always been able to forge ahead despite risks, disasters and headwinds, and humanity shall and will continue to stride forward. The overwhelming trend for countries to move toward openness and cooperation remains unchanged." 60

Not only can China, as the largest developing country, contribute to international governance, but also because of the irresponsibility, even perversity, and the threat to the international rule of law of some countries highlight the positive and important significance of China's adherence to the correct ideology of the rule of law, including the ideas and concepts of international law.

In conclusion, the propositions and series of discourses of Xi Jinping on international law inherit, adhere to and develop the Five Principles of Peaceful Coexistence, emphasize upholding peace, development, fairness, justice, democracy and freedom as the Common Values of Humanity, actively promote the building of a new type of international relations and a community with a shared future for mankind, actively promote China's reform and opening-up and foreign relations, especially in the process of strengthening the modernization of the national governance system and capacity. It also represents China's contribution to the theory of international law in modern world and will continue to promote China's greater contribution to the international governance of law.

\section{Bibliography}

"Proposal of the Central Committee of the Communist Party of China on Formulating the

\footnotetext{
${ }^{59}$ See Fabio Marcelli, "A Shared Future of Mankind: a New Concept and its Paramount Pedagogical Importance", Advances in Social Science, Education and Humanities Research, Vol. 135, 2019, pp. 9-15.

${ }^{60} \mathrm{Xi}$ Jinping, "Keynote Speech at the Opening Ceremony of the Third China International Import Expo", People's Daily, November 5, 2020, p.2.
} 
Fourteenth Five-Year Plan for National Economic and Social Development and the Visionary Goals for 2035", People's Daily, November 4, 2020, p. 4.

"Proposal of the Central Committee of the Communist Party of China on Formulating the Fourteenth Five-Year Plan for National Economic and Social Development and the Visionary Goals for 2035", People's Daily, p. 4.

"Unswervingly Follow the Path of the Socialist Rule of Law with Chinese Characteristics, and Provide a Strong Legal Guarantee for the Comprehensive Construction of a Modern Socialist Country", People's Daily, November 18, 2020, pp. 1 and 4.

António Guterres, Remarks to the UN Human Rights Council, 27 February 2017, www.un.org/sg/en/content/sg/speeches/2017-02-27/ secretary-generalshuman-rights-council-remarks, last visited on November 22, 2020.

Aristotle, Politics, translated by Wu Shoupeng, Commercial Press, 1965, p. 138.

Charter of the United Nations, cited from the United Nations website, https://www.un.org/ zh/sections/un-charter/preamble/index.html, accessed on November 20, 2020.

Decision of the Central Committee of the Communist Party of China on Several Major Issues on Adhering to and Improving the Socialist System with Chinese Characteristics and Promoting the Modernization of the State Governance System and Governance Capacity, People's Publishing House, 2019, p. 38.

Decision of the Central Committee of the Communist Party of China on Several Major Issues on Adhering to and Improving the Socialist System with Chinese Characteristics and Promoting the Modernization of the State Governance System and Governance Capacity, People's Publishing House, 2019, pp. 14, 38.

Deng Xiaoping, "Emancipating the Mind, Seeking Truth from Facts, Uniting to Look Forward", Deng Xiaoping, Selected Works of Deng Xiaoping, Vol. II, People's Publishing House, 2008, p. 147.

Firmly follow the path of socialist rule of law with Chinese characteristics and provide strong rule of law guarantee for the comprehensive construction of a modern socialist country," People's Daily, Nov. 18, 2020, pp. 1, 4.

Foreign Ministry Spokesperson Geng Shuang's regular press conference on January 8, 2020 , Webpage of the Chinese Ministry of Foreign Affairs: https://www.fmprc.gov.cn/web/wjdt_674879/fyrbt_674889/t1730274.shtml , last visited on November 22, 2020.

Guidance Readings on the Decision of the Central Committee of the Communist Party of China on Several Major Issues of Comprehensively Promoting the Rule of Law, People's Publishing House, 2018, p. 33.

Huang Jin, "How to Strengthen the Cultivation of Foreign-Related Rule of Law Talents," Legal Daily, November 20, 2019, p. 9; Huang Huikang, Great Power Diplomacy with Chinese Characteristics and International Law, Law Press, 2019, p. 494.

International Covenant on Civil and Political Rights and International Covenant on Economic, Social and Cultural Rights, Office of the United Nations High Commissioner for 
Human Rights, cited respectively from the United Nations website, https://www.un.org/zh/documents/treaty/files/A-RES-2200-XXI-2-new. shtml,https://www.un.org/zh/documents/treaty/files/A-RES-2200-XXInew.shtml, last visited on November 20, 2020.

James W. Davis,"A Critical View of Global Governance", Swiss Political Science Review, Vol. 18, No. 2,2012, pp. 272-286.

Jia Bingbing, "An Analysis of the Problem of "Legal Uncertainty" in International Law", Chinese International Law Society, Chinese Yearbook of International Law, vol. 2013, Law Press, 2014, pp. 73-92.

Jon Barnett,Peace and Development,"Towards a New Synthesis",Journal of Peace Research, Vol. 45, No. 1,2008, pp.75-89.

Katharine Wright \& Julian Sheather, "The Role of Solidarity in Research in Global Health Emergencies ",The American Journal of Bioethics, vol. 20, no. 5, 2020, p. 4.

Lina Zong et al. "A Chinese Solution for Innovative Child-Friendly City Construction - Ecological Construction of Child-Friendly Education Complex in China Children's Center," Beijing Planning and Construction, No. 3, 2020.

Malcolm N. Shaw, International Law, 8th edition, Cambridge University Press, 2017,pp.301-302.

Marcelli Fabio, "A Shared Future of Mankind: a New Concept and its Paramount Pedagogical Importance",Advances in Social Science, Education and Humanities Research, Vol. 135, 2019, pp. 9-15.

Nansu, "The First Child-Friendly Town Creation in China Launched," Zhejiang Daily, August 18, 2020, p. 11.

Proposal of the Central Committee of the Communist Party of China on Formulating the Fourteenth Five-Year Plan for National Economic and Social Development and the Visionary Goals for 2035, People's Daily, November 4, 2020, p. 1.

Proposal of the Central Committee of the Communist Party of China on Formulating the Fourteenth Five-Year Plan for National Economic and Social Development and the Visionary Goals for 2035, People's Daily, November 4, 2020, p. 4.

Staiano Maria Francesca-Marcelli Fabio, "Challenges, Reflections and Prospects of the COVID19 Global Epidemic", translated by Li Jiang, Chinese Review of International Law, Issue 4, 2020, pp. 3-23.

United Nations Development Programme, China, Development Research Center of the State Council, China Human Development Report 2016, China Translation Press, 2016, pp. 17-30.

Wang Yi, "China is a Firm Defender and Builder of the International Rule of Law," Guangming Daily, October 24, 2014, p. 2.

Xi Jinping, "A New Partnership of Mutual Benefit and Community of Shared Future," in Xi Jinping, Governance of China, Vol. II, Foreign Languages Press, English version, 2017, p. 522. 
Xi Jinping, "Advance the Rule of Law Under the Chinese Socialism," in Xi Jinping, Governance of China, Vol. III, p. 333.

Xi Jinping, "Championing Discussion and Collaboration for Shared Growth as a Principle of Global Governance ", Xi Jinping, On Building a Human Community with a shared future, p. 270.

Xi Jinping, "Championing Discussion and Collaboration for Shared Growth as a Principle of Global Governance", Xi Jinping, On Building a Human Community with a Shared Future, p.271.

Xi Jinping, "Championing the Five Principles of Peaceful Coexistence, Building a Better World Through Win-Win Cooperation", Xi Jinping, On Building a Human Community with a shared future, p. 141.

Xi Jinping, "Following the Trends of our Time and Promoting World Peace and Development", Xi Jinping, On Building a Human Community with a shared future, p. 7, March 23, 2013.

Xi Jinping, "Improving Our Ability to Participate in Global Governance", Xi Jinping, On Building a Human Community with a shared future, p. 397.

Xi Jinping, "Improving Our Ability to Participate in Global Governance", Xi Jinping, On Building a Human Community with a shared future, p.397.

Xi Jinping, "Improving our Ability to Participate in Global Governance", Xi Jinping, On Building a Human Community with a shared future, pp.398,399.

Xi Jinping, "Keynote Speech at the Opening Ceremony of the Third China International Import Expo", People's Daily, November 5, 2020, p.2.

Xi Jinping, "Promote Socialist Rule of Law," Xi Jinping, The Governance of China, Vol.II, Foreign Languages Press, English version, 2017, p. 126.

Xi Jinping, "Protect and Promote Human Rights in the Chinese Context," in Xi Jinping, Governance of China,Vol. III, Foreign Languages Press, English version, 2020, pp. 337.

Xi Jinping, "Remember the Past and Our Martyrs, Cherish Peace, and Build a New Future," in Xi Jinping, Governance of China, Vol. II, p.485.

Xi Jinping, "Speech at the 75th Anniversary Summit of the United Nations", People's Daily, September 21, 2020, p. 2.

Xi Jinping, "Speech at the second full assembly Central Committee " , Xi Jinping, The LawBased Governance of China, Central Compilation \& Translation Press, English version, 2017. pp.12,13.

Xi Jinping, "Speech at the Summit Commemorating the 75th Anniversary of the Founding of the United Nations", People's Daily, September 22, 2020, p.2.

Xi Jinping, "Taking the Road of Human Rights Development in Accordance with National Conditions," in Xi Jinping, Governance of China, Vol. III, p. 288.

Xi Jinping, "Toward a Community of Shared Future for Mankind," in Xi Jinping, Governance of 
China, Vol. II, pp. 590,591.

Xi Jinping, "Toward a Mutually Beneficial Partnership for Sustainable Development", Xi Jinping, On Building a Human Community with a shared future, pp. 258,259.

Xi Jinping, "Toward a Mutually Beneficial Partnership for Sustainable Development", Xi Jinping, On Building a Human Community with a shared future, pp.258,259.

Xi Jinping, "Towards a Community of Shared Future for Mankind," Xi Jinping, Governance of China, Vol. II, pp.591,592.

Xi Jinping, "Using the Thought on Diplomacy for New-Era Socialism with Chinese Characteristics as a Guide to Create a New Landscape in Major Country Diplomacy with Chinese Characteristics" , Xi Jinping, On Building a Human Community with a shared future, Central Compilation \& Translation Press, English version, 2019, p.551. pp.258,259.

Xi Jinping, "Watch and Help Each Other to Overcome the Pandemic and Work Together to Advance Cooperation", People's Daily, November 18, 2020, p.2.

Xi Jinping, "Working Together for New Progress of Security and Development in Asia- Speech at the Fifth Summit of the Conference on Interaction and Confidence-Building Measures in Asia (CICA)", People's Daily, June 16, 2019, p.2.

Xi Jinping, "Working Together to Forge a New Partnership of Mutually Beneficial Cooperation and Create a Human Community with a Shared Future", Xi Jinping, On Building a Human Community with a shared future, p. 265.

Xi Jinping, Build a moderately prosperous society across the board and seizing the great victory of socialism with Chinese characteristics in the new era - Report at the 19th National Congress of the Communist Party of China, People's Publishing House, 2017, p. 58.

Xi Jinping: "Carry forward the Shanghai Spirit; Build a Community of Shared Future", in Xi Jinping, Governance of China, Vol. III, p. 511.

Xi Jinping: "Speech at the Conference Commemorating the 70th Anniversary of the Chinese People's Volunteer Army's Fight Against the U.S. and Aid North Korea", People's Daily, October 24, 2020, p. 2.

Xu Chongde, History of the Constitution of the People's Republic of China, Fujian People's Publishing House, 2005, p. 481.

Xu Hong, "The Community of Shared Future of Mankind and International Law," Chinese Review of International Law, Issue 5, 2018, pp.8-10

Zhang Cong, "The Preamble of the Constitution also has the highest legal effect - Interview with Li Lin, Member of the Chinese Academy of Social Sciences(CASS) and former Director of the Institute of Law, CASS, in People's Daily, March 9, 2018, p. 14.

Zhao Hong, "International Law at the Crossroads: Ideals and Realities of the International Rule of Law," International Trade, Issue 2, 2020, p. 7. 